\title{
Anti-dsDNA antibodies in Brazilian patients of mainly African descent with systemic lupus erythematosus: lack of association with lupus nephritis
}

\author{
A. M. Atta • M. M. Pereira • M. Santiago • \\ M. L. B. Sousa-Atta
}

Received: 11 April 2008 /Revised: 8 February 2009 /Accepted: 9 February 2009/Published online: 13 March 2009

(C) Clinical Rheumatology 2009

\begin{abstract}
Renal disease is associated with morbidity and mortality in systemic lupus erythematosus (SLE) and antidsDNA antibodies with SLE immunopathogenesis. We investigated the dsDNA antibody profile of 84 Brazilian SLE patients, 27 with lupus nephritis. Thirty-six (39.1\%) patients had dsDNA IgG antibodies shown in enzymelinked immunosorbent assay (454.7 \pm 281.1 WHO units/ $\mathrm{mL}$ ), nine presenting renal disease. The following profile of dsDNA antibodies was demonstrated in Crithidia luciliae test: IgA (seven out of $36 ; 19.4 \%$ ), IgG (22 out of 36 , $66.1 \%$ ); IgM (nine out of $36,25.0 \%$ ), and $\operatorname{IgE}$ (four out of $36,11.1 \%)$. Two or three isotypes of dsDNA antibodies were observed in nine $(25.0 \%)$ patients, while $11(30.5 \%)$ were seronegative in the $C$. luciliae test. Patients with dsDNA antibodies had lower serum C3 and C4 when compared with SLE individuals without these immunoglobulins $(P<0.01$ and $P<0.001$, respectively). There was no association between any dsDNA antibody isotype and lupus kidney disease nor was anti-dsDNA IgM antibody associated with absence of nephritis.
\end{abstract}

\footnotetext{
A. M. Atta $\cdot$ M. M. Pereira $\cdot$ M. L. B. Sousa-Atta Departamento de Análises Clínicas e Toxicológicas, Faculdade de Farmácia, Universidade Federal da Bahia, 40170115 Salvador, Bahia, Brazil

M. Santiago

Serviço de Reumatologia do Hospital Santa Izabel, Escola Bahiana de Medicina e Saúde Pública (EBMSP), 40000000 Salvador, Bahia, Brazil

A. M. Atta $(\bowtie)$

Faculdade de Farmácia da UFBA,

Rua Barão de Geremoabo s $/ \mathrm{n}^{\circ}$, Ondina,

40170115 Salvador, Bahia, Brazil

e-mail: ajatta@ig.com.br
}

Keywords Brazil · dsDNA antibody · Isotype · Nephritis · Systemic lupus erythematosus

\section{Introduction}

Systemic lupus erythematosus exhibits a wide spectrum of clinical manifestations and exquisite diversity of autoantibodies. An important cause of both morbidity and mortality in SLE, which affects about a half of the SLE patients, is lupus kidney disease caused by glomerular immune complex deposits of autoantibodies, which is manifested by nephritis, edema, and arterial hypertension. It is documented by laboratory findings of urinary abnormalities, which are represented by proteinuria, hematuria, and urinary cellular casts. AntidsDNA antibodies and hypocomplementemia are also used as immunological markers to identify its clinical forms [1-4].

Despite the results of recent studies showing a possible pathogenic role of anti-nucleosome and anti-Clq antibodies in lupus nephritis, anti-dsDNA antibodies are still the most studied autoantibodies in SLE. However, their usefulness in evaluating the activity of SLE or diagnosing lupus nephritis apparently depends on several aspects, which include ethnicity, antibody charge, antibody isotype, epitope specificity, and affinity [5-12].

Immunoassays to detect dsDNA antibodies may differ in either sensitivity or specificity. Although the FARR immunoassay is the most efficient test to detect these immunoglobulins, and its results have been well correlated with global SLE activity, and renal and vasculitis involvement, it has been substituted in rheumatology laboratories by non-isotopic techniques, mainly indirect fluorescent antibody test (IFAT) using antigen circular dsDNA of Crithidia luciliae kinetoplast and enzyme-linked immunosorbent assays (ELISA) with purified dsDNA [10]. 
Although SLE is a rheumatic disease that affects all races, several epidemiological studies have shown an elevated prevalence of lupus nephritis in African descendents [13]. In addition, it has been well documented that presentation of systemic autoimmune diseases is influenced by the distribution of MHC-II alleles and also by polymorphisms in genes controlling autoantibody production [14]. In Brazil, where there are many African descendents, there is no government data on SLE prevalence, being estimated that 16,000-80,000 Brazilian people may have this disease, using the data obtained from other countries as a reference [15].

The aim of this study was to investigate the presence of dsDNA-antibodies and their isotypes in a subset of Brazilian SLE patients living in the state of Bahia, whose population is mainly represented by African descendents and has distinct environmental factors [16]. The association between these autoantibodies, hypocomplementemia, and lupus nephritis was also evaluated.

\section{Material and methods}

Patients Eighty-four Brazilian SLE patients (80 women and four men; median age 39 years, ranging from 14 to 73 years) living in the state of Bahia, who were enrolled in a study of prevalence of Jaccoud's arthropathy at the Lupus Ambulatory of the Santa Izabel Hospital in Salvador were evaluated. They had four or more criteria for SLE in accordance with the revised American Rheumatology College criteria [17] and were included consecutively regardless of the presence of Jaccoud's arthropathy. All patients were seropositive for antinuclear antibodies in both IFAT with HEp-2 cell and ELISA, presenting a mean titer of ANA of 113.2 $\pm 60.0 \mathrm{U}$ (CI $95 \%=100.2-126.3 \mathrm{U}$; cutoff point=20 U) in the QUANTA Lite ${ }^{\mathrm{TM}}$ ANA ELISA (INOVA Diagnostics, San Diego, CA, USA). The duration of the disease in these individuals ranged from 2 months to 24 years, with a median of 5 years at the time they were included in this study. Lupus nephritis was investigated by dipstick proteinuria, microscopic urinalysis of abnormalities in urinary sediment (more than five RBC or WBC/high-powered field, and granular casts), and urine protein-to-creatinine ratio in an untimed urine specimen and serum creatinine level [3, 4]. Kidney biopsy was not performed in SLE individuals.

Most patients used medication, which was mainly represented by prednisone, alone or mainly combined with chloroquine, azathioprine, or cyclophosphamide. Consent was obtained from all individuals, and the study was approved by the Human Research Ethics Committee of the Santa Izabel Hospital.

dsDNA antibodies Anti-dsDNA IgG antibodies were screened by indirect ELISA (QUANTA Lite ${ }^{\mathrm{TM}}$ dsDNA
ELISA, INOVA), using polystyrene microwell ELISA plate coated with a highly purified calf thymus dsDNA antigen and serum diluted at 1:100. As recommended by the manufacturer, titers of dsDNA antibodies were classified as moderate (139.0-370.4 WHO units/mL) and high titer ( $\geq 370.5 \mathrm{WHO}$ units $/ \mathrm{mL}$ ) in accordance with its previous studies. Anti-dsDNA IgG and IgM antibodies were probed in sera diluted at 1:10 in phosphate-buffered saline (PBS) by indirect immunoperoxidase with Crithidia luciliae dsDNA and peroxidase conjugate of goat anti-human IgG and goat anti-human IgM, respectively. Using this same serum dilution, anti-dsDNA IgA antibodies were tested by indirect fluorescent antibody test (IFAT) with $C$. luciliae and goat anti-human IgA FITC conjugate.

To investigate the presence of anti-dsDNA IgE antibodies, SLE sera were first depleted of IgG with Protein G-Sepharose beads $\left(Z Y M E D{ }^{\circledR}\right.$ Laboratories, San Francisco, CA, USA) and tested diluted at 1:6 in PBS in $C$. luciliae immunoperoxidase using monoclonal anti-human $\mathrm{IgE}$ antibody and goat anti-mouse IgG peroxidase conjugated. The immune reaction of dsDNA $\operatorname{IgE}, \operatorname{IgG}$, and $\operatorname{IgM}$ antibodies with $C$. luciliae kinetoplast was revealed with 4-chloro-1-naphtol.

Complement evaluation C3 and C4 were determined by turbidimetry using goat IgG antibodies against these proteins (Sigma), and a reference curve made with a Tru-Cal Protein kit (Dyasis Diagnostic Systems GmbH, Holzheim, Germany). The reference levels were $79-152 \mathrm{mg} / \mathrm{dL}$ for $\mathrm{C} 3$ and $16-$ $38 \mathrm{mg} / \mathrm{dL}$ for $\mathrm{C} 4$.

Statistical analysis The titers of ANA, dsDNA-ELISA, and the serum levels of $\mathrm{C} 3$ and $\mathrm{C} 4$ were expressed as mean $\pm \mathrm{SD}$ and $95 \%$ confidence interval. The urine protein-to-creatinine ratio and serum level of creatinine were expressed as median and interquartile range (IQR). The Mann-Whitney test was used to analyze the difference between groups, while the Fisher exact test evaluated the association between categorical groups. The statistical significance was set $P<0.05$. The GraphPad statistical software Prism 5.0 was used to perform the analysis.

\section{Results}

Twenty-seven patients had laboratory evidence of nephritis demonstrated by elevated dipstick proteinuria with hematuria $(n=13)$ and/or cellular casts $(n=7)$ in their urine exams. Their urine protein-to-creatinine $(\mathrm{P} / \mathrm{C})$ ratio measured in an untimed urine specimen was increased and presented a median of $1.15 \mathrm{mg} / \mathrm{mg}$ (IQR $0.51-2.30 \mathrm{mg} / \mathrm{mg}$ ). Their serum level of creatinine had a median of $1.10 \mathrm{mg} / \mathrm{dL}$ $(\mathrm{IQR}=0.8-1.9 \mathrm{mg} / \mathrm{dL})$. In the group without nephritis $(n=$ $57)$ the urine $\mathrm{P} / \mathrm{C}$ ratio had a median of $0.43(\mathrm{IQR}=0.31-$ 
Table 1 Laboratory characteristics of SLE patients

\begin{tabular}{lccc}
\hline & Nephritis $(n=27)$ & Without nephritis $(n=57)$ & $P$ value \\
\hline P/C ratio $(\mathrm{mg} / \mathrm{mg})$ & $1.15(0.51-2.30)$ & $0.43(0.31-0.73)$ & $<0.001$ \\
Creatinine $(\mathrm{mg} / \mathrm{dL})$ & $1.10(0.8-1.9)$ & $0.80(0.7-1.0)$ & $<0.001$ \\
$\mathrm{C} 3(\mathrm{mg} / \mathrm{dL})$ & $124.1 \pm 30.63$ & $123.5 \pm 24.26$ & Not significant \\
C4 $(\mathrm{mg} / \mathrm{dL})$ & $30.08 \pm 13.70$ & $27.35 \pm 10.23$ & Not significant \\
dsDNA ${ }^{\mathrm{a}}$ antibody $($ WHO units/mL) & $399.9 \pm 183.6$ & $473.0 \pm 307.6$ & Not significant \\
\hline
\end{tabular}

Anti-dsDNA antibodies , $\mathrm{C} 3$ and $\mathrm{C} 4$ are expressed as mean $\pm \mathrm{SD}$, while $\mathrm{P} / \mathrm{C}$ ratio and creatinine are expressed as median and interquartile range due to their statistic distribution

${ }^{a}$ Anti-dsDNA antibodies were investigated in nine SLE patients with laboratory evidence of nephritis and in 27 SLE subjects without this evidence

$0.73 \mathrm{mg} / \mathrm{mg}, P<0.001)$, and the median of serum creatinine was $0.8 \mathrm{mg} / \mathrm{dL}$ (IQR $=0.7-1.0 \mathrm{mg} / \mathrm{dL}, P<0.001$; Table 1$)$.

Sera from 36 of $84(42.8 \%)$ SLE subjects reacted in dsDNA-ELISA (mean titer $=454.7 \pm 281.1 \mathrm{WHO}$ units $/ \mathrm{mL}$; CI $95 \%=359.6-549.8 \mathrm{WHO}$ units $/ \mathrm{mL})$. Half of these patients had moderate titers of dsDNA-antibodies $(226.8 \pm 66.1 \mathrm{WHO}$ units $/ \mathrm{mL}$; CI95\% $=194.0-259.7 \mathrm{WHO}$ units $/ \mathrm{mL}$ ), while the others had high titers of these immunoglobulins (682.9 \pm 219.2 WHO units $/ \mathrm{mL}$; CI95\% $=573.9-791.9$ WHO units/ $\mathrm{mL}$ ). No difference was observed between the titers of dsDNA IgG antibodies of SLE patients with nephritis $(n=9$; $399.9 \pm 183.6$ WHO units $/ \mathrm{mL}$ ) when they were compared with the titer of these antibodies in SLE patients without nephritis $(n=27 ; 473.0 \pm 307.6$ WHO units $/ \mathrm{mL}, P>0.05$; Table 1). Nephritis was not associated with the presence of dsDNA IgG antibody detected by ELISA or any isotype of dsDNA antibody in the C. luciliae test. Absence of proteinuria, hematuria, or cellular casts in SLE patients was not associated with the presence of dsDNA IgM antibodies.

Twenty-two of $36(61.1 \%)$ patients that were seropositive for dsDNA IgG in ELISA were positive for these antibodies in $C$. luciliae test. Five sera exhibiting high titers of antidsDNA IgG antibodies in ELISA (range 371-1,029 WHO

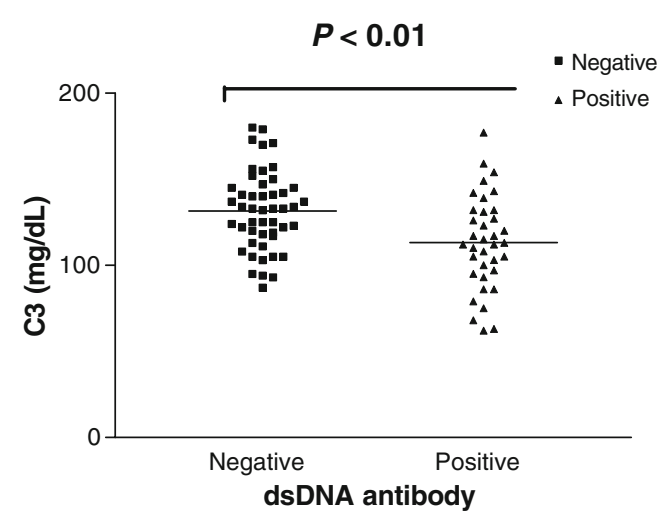

Fig. 1 Serum level of complement C3 in SLE patients seronegative and seropositive for dsDNA IgG antibodies. Anti-dsDNA antibodies were detected by using QUANTA Lite ${ }^{\mathrm{TM}}$ dsDNA ELISA (INOVA). Horizontal lines represent the mean levels of $\mathrm{C} 3$ units $/ \mathrm{mL}$ ) were negative in indirect immunoperoxidase, while eight sera showing moderate dsDNA IgG antibody titers in ELISA $(<370.4 \mathrm{WHO}$ units $/ \mathrm{mL})$ were reactive.

Anti-dsDNA IgA, IgM, and IgE antibodies were observed in seven (seven out of $36 ; 19.4 \%$ ), nine (nine out of 36 ; $25.0 \%$ ), and four (four out of $36 ; 11.1 \%$ ) patients, respectively. Sera from nine patients (nine out of 36; 25.0\%) exhibited two or three isotypes of dsDNA antibodies in $C$. luciliae test, whereas $11(11 / 36 ; 30.5 \%)$ were negative for the three isotypes of dsDNA antibodies investigated in this assay.

The levels of serum $\mathrm{C} 3$ and $\mathrm{C} 4$ in the patients that were seropositive for dsDNA IgG antibodies in ELISA were $112.8 \pm 28.2 \mathrm{mg} / \mathrm{dL}$ (CI 95\%=102.8-122.8 mg/dL) and $23.5 \pm 8.6 \mathrm{mg} / \mathrm{dL}(\mathrm{CI} 95 \%=20.6-26.4 \mathrm{mg} / \mathrm{dL})$, respectively. In SLE individuals that were seronegative for such antibodies, the levels of these proteins were $\mathrm{C} 3=131.6 \pm 22.9 \mathrm{mg} / \mathrm{dL}$ (CI $95 \%=124.9-138.2 \mathrm{mg} / \mathrm{dL}$ ) and $\mathrm{C} 4=31.8 \pm 12.1 \mathrm{mg} / \mathrm{dL}$ $(\mathrm{CI} 95 \%=28.3-35.3 \mathrm{mg} / \mathrm{dL})$, respectively. Both $\mathrm{C} 3$ and $\mathrm{C} 4$ levels were diminished in SLE patients that were seropositive for dsDNA IgG antibodies when they were compared with SLE individuals without these immunoglobulins $(P<$ 0.01 ; Figs. 1 and 2). There was an association between the

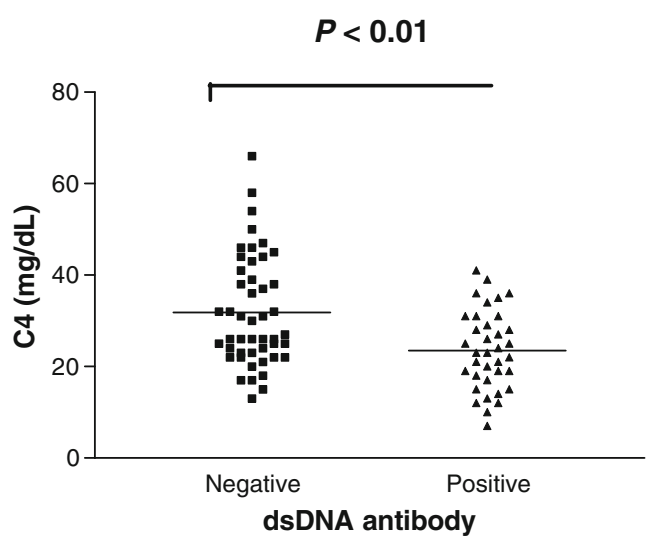

Fig. 2 Serum level of complement C4 in SLE patients seronegative and seropositive for dsDNA IgG antibodies. Anti-dsDNA antibodies were detected by using QUANTA Lite ${ }^{\mathrm{TM}}$ dsDNA ELISA (INOVA). Horizontal lines represent the mean levels of $\mathrm{C} 4$ 
presence of anti-dsDNA antibodies and low levels of both C3 $(<80 \mathrm{mg} / \mathrm{dL})$ and $\mathrm{C} 4(<16 \mathrm{mg} / \mathrm{dL} ; P<0.05)$. The serum levels of both $\mathrm{C} 3$ and $\mathrm{C} 4$ were not different when SLE group with nephritis was compared with SLE group without this clinical manifestation (Table 1).

\section{Discussion}

In this study, the presence of anti-dsDNA autoantibodies in a subset of Brazilian patients with SLE assisted in a reference center in the city of Salvador (Bahia) was investigated, and it was verified that most of the individuals treated with corticosteroids and/or cytotoxic drugs had dsDNA IgG, which were mainly detected by an ELISA using highly purified dsDNA antigen from calf thymus. However, the number of subjects that were seropositive for these immunoglobulins diminished when their sera were probed with a $C$. luciliae test, confirming the findings of previous serological studies, which evaluated the sensitivity of these two tests to detect dsDNA antibodies in SLE patients [5-12].

ELISA detects low affinity dsDNA IgG antibodies and antibodies of this isotype produced against minor epitopes of calf thymus dsDNA, which are not reactive with circular dsDNA of $C$. luciliae kinetoplast. In addition, change in dsDNA antigenicity may be produced after this nucleic acid is immobilized on the polystyrene surface of the ELISA plate, allowing the detection of IgG antibodies not directed for dsDNA in SLE sera, contributing to the higher sensitivity of ELISA [10]. Nevertheless, no positive reaction was verified for the control sera used in this work, and a more recent study in the authors' laboratory, investigating dsDNA antibodies in Brazilian hepatitis $\mathrm{C}$ virus carriers seropositive for ANA confirmed the high specificity of the QUANTA Lite $^{\text {TM }}$ dsDNA ELISA [18].

Although proteinuria was not associated with dsDNA antibodies and was absent in about two thirds of patients producing dsDNA IgG, the serum level of both $\mathrm{C} 3$ and $\mathrm{C} 4$ was significantly diminished in individuals who were seropositive for this antibody isotype when they were compared with SLE subjects from the same group without this immunoglobulin. Such a finding needs to be investigated in prospective studies to verify the risk of nephritis in these subjects since both anti-dsDNA antibodies and hypocomplementemia are complementary to proteinuria in renal disease in SLE patients [3].

Anti-dsDNA IgA antibodies were found in moderate prevalence, but were always detected together with dsDNA IgG antibodies. Previously, dsDNA IgA antibodies were associated with lupus activity, demonstrated by elevated erythrocyte sedimentation rate and consumption of complement C3, vasculitis, but not with nephritis [19].
Anti-dsDNA IgM antibodies were always found together with dsDNA IgG antibodies in ELISA, while in immunoperoxidase with $C$. luciliae, only a few sera had both dsDNA IgM and dsDNA IgG antibodies. Although antidsDNA IgM antibodies have been associated with absence of lupus nephritis in a previous report using IgM-ELISA [20], such a finding was not observed in our study. However, the use of immunoperoxidase to detect $\operatorname{IgM}$ antibodies, which is less sensitive and more specific than ELISA, may justify these divergent results.

Anti-dsDNA IgE antibodies were observed in a few patients that were seropositive for dsDNA IgG in ELISA, but only one had proteinuria. Lupus activity and lupus nephritis have frequently been demonstrated in patients without allergy, exhibiting increased level of serum IgE. Furthermore, glomerular deposits of $\operatorname{IgE}$ were found in the kidney biopsies from patients with lupus nephritis [21-26].

Although dsDNA antibodies have been associated with lupus activity and nephritis, we were unable to show this association in SLE patients with laboratory evidence of renal disease as demonstrated by urinary abnormalities, increased serum creatinine, and mainly an increased urine protein-to-creatinine $(\mathrm{P} / \mathrm{C})$ ratio, which corresponds to a clinically significant total $24 \mathrm{~h}$ proteinuria [27]. Nevertheless, the synthesis of dsDNA antibodies depends on both innate and acquired immunity, and may be induced by bacterial DNA. In addition, dsDNA antibodies can be detected several years before clinical manifestations of lupus and present a broad reactivity in SLE patients. Furthermore, lupus renal disease can develop without dsDNA antibodies, and only dsDNA IgG antibodies with residues of arginine in their heavy and light chain complementarity-determining regions (CDRs) are nephritogenic [28-31]. Thus, our results suggest that dsDNA antibodies without these CDR features may be prevalent in the subset of Brazilian SLE patients studied. At present, studies have been performed in our laboratory to elucidate the immunochemical features of the dsDNA antibodies here detected and also to identify in the SLE patients other autoantibodies that have been also associated with lupus nephritis as $\mathrm{C} 1 \mathrm{q}$ and nucleosome antibodies.

Disclosures None.

\section{References}

1. Mok CC, Lau I (2003) Pathogenesis of systemic lupus erythematosus. J Clin Pathol 56:481-490

2. Borchers AT, Keen CL, Shoenfeld Y, Gershwin ME (2004) Surviving the butterfly and the wolf: mortality trends in systemic lupus erythematosus. Autoimmun Rev 3:423-453

3. Illei GG Balow JE (2007) Kidney involvement in systemic lupus erythematosus. In: Tsokos GC, Gordon C, Smolen JS (eds) 
Systemic Lupus Erythematosus: a companion to Rheumatology, 1st edn. Mosby Elsevier, Philadelphia, pp 336-350

4. Dooley MA (2007) Clinical and laboratory features of lupus nephritis. In: Wallace DJ, Hahn BH (eds) Dubois' lupus erythematosus, 7th edn. Lippincott Williams \& Wilkins, Philadelphia, pp 1112-1130

5. Tzioufas AG, Terzoglou C, Stavropoulos ED, Athanasiadou S, Moutsopoulos HM (1990) Determination of anti-ds-DNA antibodies by three different methods: comparison of sensitivity, specificity and correlation with lupus activity index (LAI). Clin Rheumatol 9:186-92

6. Smeenk RJT (2002) Detection of antibodies to dsDNA: current insights into its relevance. Clin Exp Rheumatol 20:294-300

7. Rahman A, Hiepe F (2002) Anti-DNA antibodies-overview of assays and clinical correlations. Lupus 11:770-773

8. Isenberg D, Smeenk R (2002) Clinical laboratory assays for measuring anti-dsDNA antibodies. Where are we now? Lupus 11:797-800

9. Isenberg D (2004) Anti-dsDNA antibodies: still a useful criterion for patients with systemic lupus erythematosus? Lupus 13:881885

10. Rouquette AM, Desgruelles C (2006) Detection of antibodies to dsDNA: an overview of laboratory assays. Lupus 15:403-407

11. Yung S, Chan TM (2008) Anti-DNA antibodies in the pathogenesis of lupus nephritis - the emerging mechanisms. Autoimmun Rev 7:317-321

12. Hahn BH, Tsao BP (2007) Antibodies to DNA. In: Wallace DJ, Hahn BH (eds) Dubois' lupus erythematosus, 7th edn. Lippincott Williams \& Wilkins, Philadelphia, pp 442-463

13. Lau CS, Gin Y, Mok CC (2006) Ethnic and geographical differences in systemic lupus erythematosus: an overview. Lupus 15:715-719

14. Conrad K, Bachmann M (2006) Autoantibodies and systemic autoimmune diseases. In: Pollard KM (ed) Autoantibodies and autoimmunity: molecular mechanisms in health and disease, 1st edn. WILEY-VCH Verlag GmbH \& Co. KGaA, Weinheim, pp 225-245

15. Sato E. Lupus Eritematoso sistêmico. Principais doenças em reumatologia. Sociedade Brasileira de Reumatologia. www.sbr. org.br

16. Vilar MJ, Sato EI (2002) Estimating the incidence of systemic lupus erythematosus in a tropical region (Natal, Brazil). Lupus $11: 528-532$
17. Hochberg MC (1997) Updating the American College of Rheumatology revised criteria for the classification of systemic lupus erythematosus. Arthritis Rheum 40:1725

18. Sousa Atta MLB, Margarida PE, Leite BC, Pereira CM, Paraná R, Atta AM (2006) Autoimmune aspects of hepatitis C in Bahia (Brazil). J Clin Rheum 12(supplement):S6

19. Witte T, Hartung K, Matthias T et al (1998) Association of IgA anti-dsDNA antibodies with vasculitis and disease activity in systemic lupus erythematosus. SLE Study Group. Rheumatol Int 18:63-69

20. Witte T, Hartung K, Sachse C et al (1998) IgM anti-dsDNA antibodies in systemic lupus erythematosus: negative association with nephritis. Rheumatol Int 18:85-91

21. Rebhun J, Quismorio F, Dubois E, Heiner DC (1983) Systemic lupus erythematosus activity and IgE. Ann Allergy 50:34-36

22. Morton S, Palmer B, Muir K, Powell RJ (1998) IgE and non-IgE mediated allergic disorders in systemic lupus erythematosus. Ann Rheum Dis 57:660-663

23. McPhaul Jr JJ, Newcomb RW, Mullins JD, Thompson Jr AL, Lordon RE, Rogers PW (1974) Participation of immunoglobulin E (IgE) in immune-mediated glomerulonephritis. Kidney Int 5:292-299

24. Tuma SN, Llach F, Sostrin S, Dubois EL, Massry G (1981) Glomerular IgE deposits in patients with lupus nephritis. Am J Nephrol 1:31-36

25. Laurent J, Lagrue G, Sobel A (1986) Increased serum IgE levels in patients with lupus nephritis. Am J Nephrol 6:413-414

26. Atta AM, Sousa CP, Carvalho EM, Sousa-Atta ML (2004) Immunoglobulin $\mathrm{E}$ and systemic lupus erythematosus. Braz J Med Biol Res 37:1497-501

27. Leung YY, Szeto CC, Tam LS, Lam CWK, Li EK, Wong KC et al (2007) Urine protein-to-creatinine ratio in an untimed urine collection is a reliable measure of proteinuria in lupus nephritis. Rheumatology 46:649-652

28. Pisetsky D (2008) The role of innate immunity in the induction of autoimmunity. Autoimmun Rev 8:69-72

29. Arbuckle MR, McClain MT, Rubertone MV et al (2003) Development of Autoantibodies before the Clinical Onset of Systemic Lupus Erythematosus. N Eng J Med 349:1526-1533

30. Deshmukh US, Bagavant H, Fu SM (2006) Role of anti-DNA antibodies in the pathogenesis of lupus nephritis. Autoimmun Rev $5: 414-418$

31. Rahman A (2004) Autoantibodies, lupus and the science of sabotage. Rheumatol 43:1326-1336 